\title{
COMPLEXES OF SELECTED TRANSITION METAL IONS WITH N-MODIFIED GLYCINE AS LIGAND
}

\author{
CARMEN SACALIS ${ }^{a,{ }^{*}}$, FIRUTA GOGA $^{a}$, CRISTINA SOMESAN $^{b}$
}

\begin{abstract}
A novel series of transitional metal complexes of $\mathrm{Cu}(\mathrm{II}), \mathrm{Co}(\mathrm{II})$, $\mathrm{Ni}(\mathrm{II}), \mathrm{Zn}(\mathrm{II})$ and $\mathrm{Fe}(\mathrm{II})$ with $\mathrm{N}$-modified glycine as ligand provide from phenylserinol were synthesized and characterized via elemental analysis, MS, IR, UV-VIS thermogravimetric analysis and ESR. The thermal stability of the ligand and synthesized complexes was discussed in the $20-1000^{\circ} \mathrm{C}$ temperature range. The results indicate that the organic compound acts as a bidentate ligand, its coordination involving the carboxylate oxygen and the nitrogen atom belonging to the amino group of the glycine fragment. The shape of ESR spectrum for cooper complex at room temperature suggest an axial symmetry around the metallic ions $\left(g_{\|}=2.427, g \perp=2.063\right)$.
\end{abstract}

Keywords: glycine, transition metal complexes, thermal behavior, spectroscopic studies.

\section{INTRODUCTION}

Complexes of transition metals with amino acids like glycine, have received much attention because they proved biological activity such as antibacterial, antimicrobial or antifungal activities [1-4]. Glycine derivatives including complexes with different transition metals with antibacterial activity are also known $[5,6]$.

Other research indicated that transition metal complexes with $\mathrm{N}$ substituted glycine act as hydrogen buffer in biological reactions [7].

$\mathrm{N}$-modified glycines have a lot of applications in biomedicine as analogue of anticonvulsant and antiepileptic agent Milacemide or as buildingunits for $N$-backbone cyclic peptides [8, 9].

\footnotetext{
a Babeş-Bolyai University, Faculty of Chemistry and Chemical Engineering, 11 Arany Janos str., RO-400028, Cluj-Napoca, Romania.

* Corresponding author: cbatiu@chem.ubbcluj.ro

b Babeş-Bolyai University, Faculty of Physics, 1 Mihail Kogalniceanu str., RO-400084, Cluj-Napoca, Romania.
} 
Recently studies of transition metal complexes of mixed ligand with glycine report biological activity too [10,11].

Taking into account the important biochemical applications of $\mathrm{N}$-modified glycine, we have recently reported a new series of transition metal complexes with an other $\mathrm{N}$-modified glycine as a ligand, derived from $p$-nitrophenylserinol [12].

In continuation of our recent findings in the field of transition metal complexes with $\mathrm{N}$-modified glycine as ligand, we report herein the preparation of a new series of metal complexes with other ligand ( $\mathbf{L}$ ) prepared and reported by us, namely $2[(1 S, 2 S)-1,3$-dihydroxy-1-phenylpropan-2-yl-amino) acetic acid (Figure1) [13]. This work, that presents the synthesis, the spectroscopic and thermogravimetric investigation the metal complexes of ligand $\mathbf{L}$ whit $\mathrm{Cu}(\mathrm{II})$, $\mathrm{Co}(\mathrm{II}), \mathrm{Ni}(\mathrm{II}), \mathrm{Zn}(\mathrm{II})$ and $\mathrm{Fe}(\mathrm{II})$ ions, has the same objectives as the above quoted study.

The ligand $\mathbf{L}$, an optically active $\mathrm{N}$-modified glycine, was obtained by a literature procedure like the non-nitrated analogue, with satisfactory yield [13].<smiles>O=C(O)CN[C@@H](CO)C(O)c1ccccc1</smiles>

Figure 1. Structure formula of ligand L: 2-[(1S,2S)-1,3-dihydroxy-1-phenylpropan2-yl-amino]acetic acid

\section{RESULTS AND DISCUSSION}

\section{The structure of the metal complexes}

The complexation reaction of $\mathrm{Cu}(\mathrm{II}), \mathrm{Co}(\mathrm{II}), \mathrm{Ni}(\mathrm{II}) \mathrm{Fe}(\mathrm{II})$ and $\mathrm{Zn}(\mathrm{II})$ salt with the aqueous solution of the ligand $\mathbf{L}$ in each case yields a solid product. Except Zn(II) complex which is colorless, all are colored, microcrystalline and stable at room temperature. They are also insoluble in water (the ligand is very soluble) or non-polar organic solvents but soluble in methanol or DMSO. The different and much higher melting points of these products, as well their different colors when compared to that of the ligand $\mathbf{L}$, indicate the formation of metal complexes.

Their elemental analysis data is in agreement with the molar ratio Metal : Ligand $=1: 2$. In exchange the elemental analysis data indicate also that the ligand is hydrated with one mole of water, the copper complex with 
one mole of water too, but the other metal complexes are hydrated with two mole of water. The presence of water outside or within the sphere of coordination is demonstrated by thermal analysis data (Table 2).

The UV-VIS spectra in DMSO for the complexes (1-5) indicate a slight hypsochromical shift by 3.5-7.5 nm, but a considerable hyperchromic increase effect of absorbance comparative to the spectrum of the initial ligand (L), except Zn complex, like the other similar complexes [3, 12, 14, 15].

On the other hand, the HRMS spectrum for the metal complexes proves the complexation process (Figure 2a-c). The $M+1$ peak supports the complexation idea with the transition metal ions, for each of them.

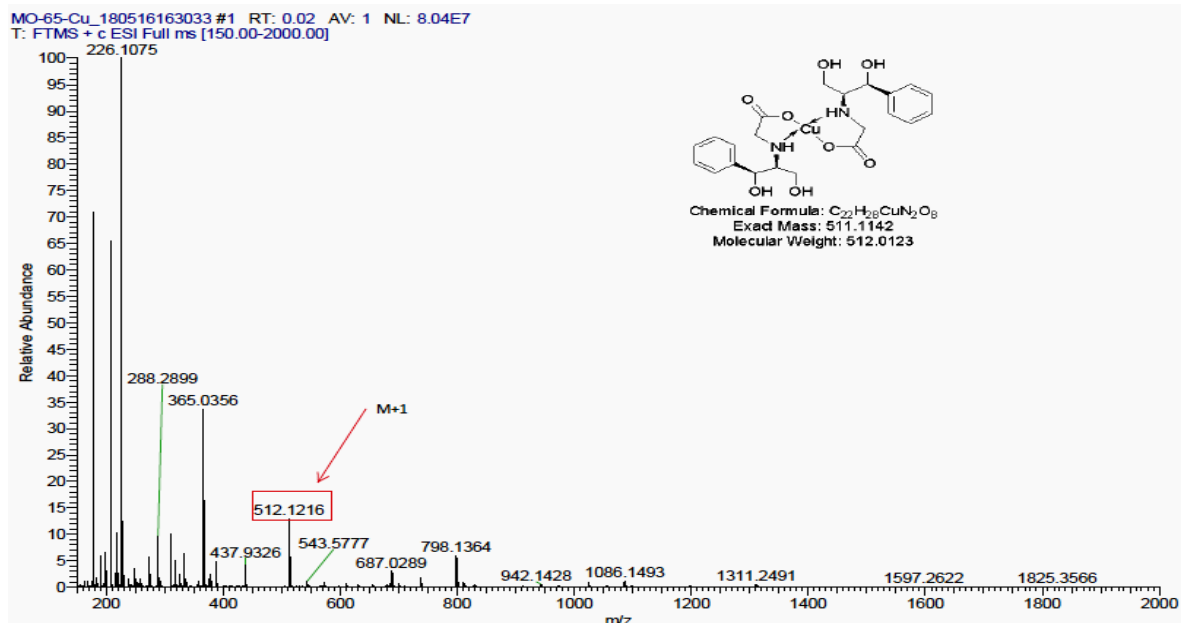

Figure 2a. HRMS spectrum (ESI) of cooper complex (1)

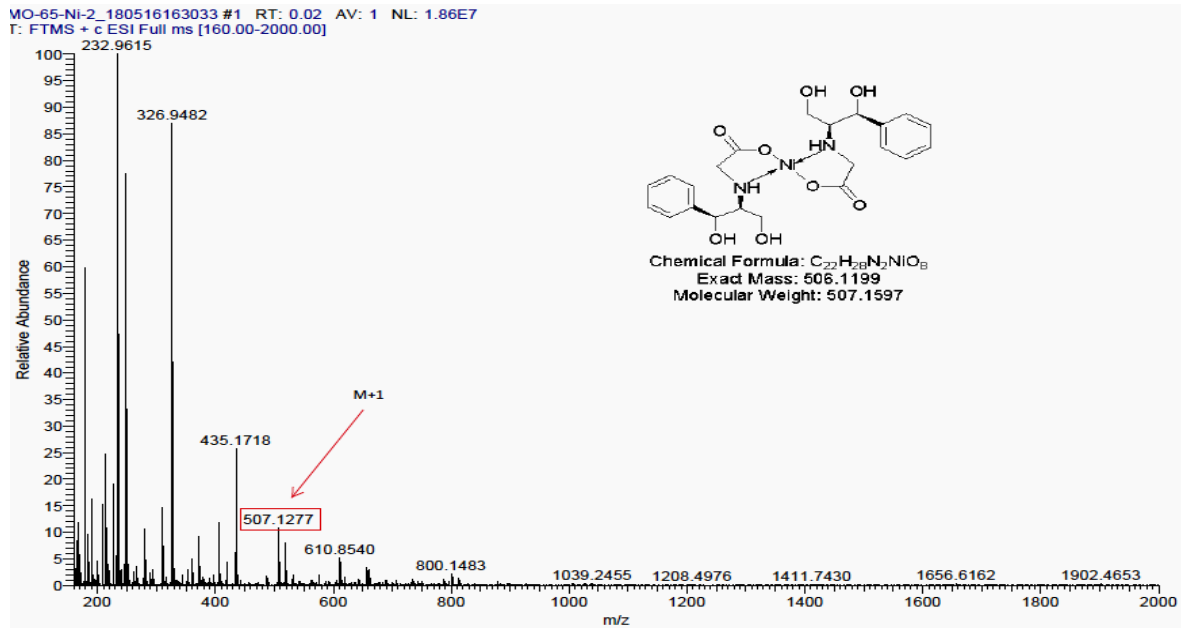

Figure 2b. HRMS spectrum (ESI) of nickel complex (3) 


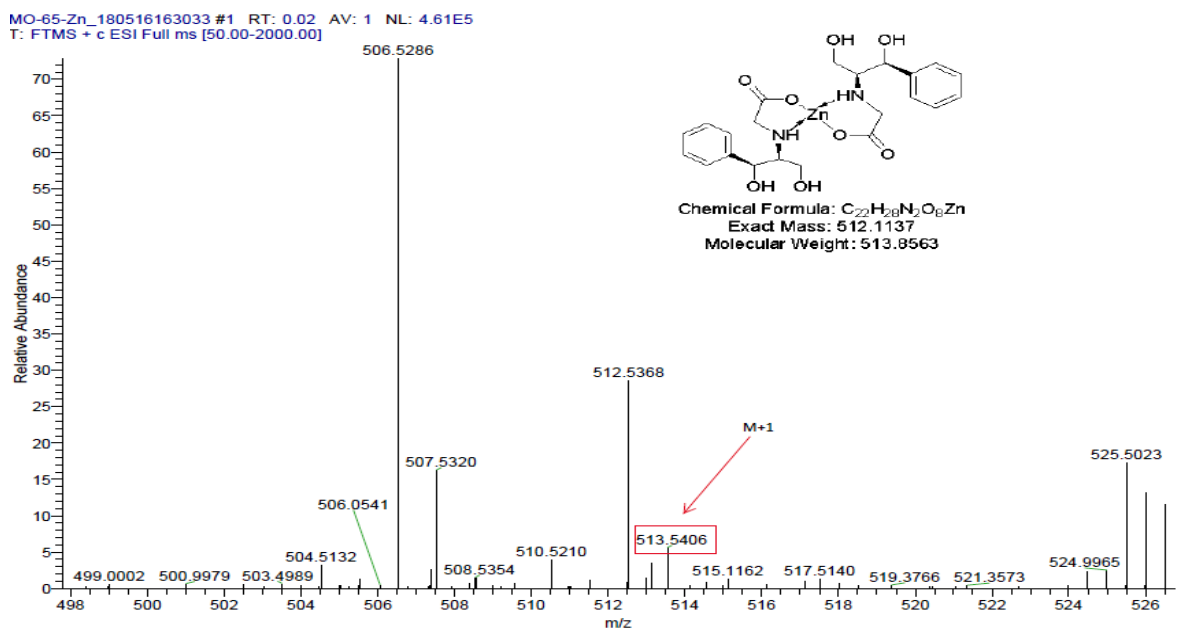

Figure 2c. HRMS spectrum (ESI) of zinc complex (5)

The bonding of the ligand to different metal ions was investigated also by comparing the IR spectrum of the free ligand with those of the metal complexes. IR spectrum of free ligand undergoes a certain modification when coordinated to a metal ion [15-20]. Partial assignments of the IR absorption bands observed for the free ligand and the metal complexes are given in Table 1

Table 1. Some IR absorption bands $\left(\mathrm{cm}^{-1}\right)$ of the ligand $\mathbf{L}$ and its metal complexes (1-5)

\begin{tabular}{|c|c|c|c|c|c|c|c|c|}
\hline $\begin{array}{c}\text { Assignment } \\
\left(\mathrm{cm}^{-1}\right)\end{array}$ & $\begin{array}{c}\mathrm{VOH}_{\mathrm{OH}} \\
\mathrm{V}_{\mathrm{O}-\mathrm{H}-\mathrm{O}}\end{array}$ & $V_{N H}$ & $v\left(\mathrm{coO}^{-}\right)$as & $v\left(\mathrm{COO}^{-}\right)_{s}$ & $\delta_{N H}$ & $V_{M-O}$ & $V_{M-N}$ & $V_{M-H 2 O}$ \\
\hline $\begin{array}{c}\mathrm{C}_{11} \mathrm{H}_{17} \mathrm{NO}_{5} \\
\text { (L) }\end{array}$ & 3367 & 3147 & 1651 & 1411 & $\begin{array}{l}1568 \\
1494\end{array}$ & - & - & - \\
\hline $\begin{array}{c}\mathrm{C}_{22} \mathrm{H}_{30} \mathrm{CuN}_{2} \mathrm{O}_{9} \\
\text { (1) }\end{array}$ & 3293 & 3034 & 1613 & 1386 & $\begin{array}{l}1494 \\
1456\end{array}$ & 421 & 541 & 763 \\
\hline $\begin{array}{c}\mathrm{C}_{22} \mathrm{H}_{32} \mathrm{CoN}_{2} \mathrm{O}_{10} \\
\text { (2) }\end{array}$ & 3324 & 3086 & 1600 & 1383 & $\begin{array}{l}1493 \\
1456\end{array}$ & 429 & 561 & 763 \\
\hline $\begin{array}{c}\mathrm{C}_{22} \mathrm{H}_{32} \mathrm{~N}_{2} \mathrm{NiO}_{10} \\
\text { (3) }\end{array}$ & 3316 & 3086 & 1603 & 1385 & $\begin{array}{l}1494 \\
1456\end{array}$ & 432 & 564 & 763 \\
\hline $\begin{array}{c}\mathrm{C}_{22} \mathrm{H}_{32} \mathrm{FeN}_{2} \mathrm{O}_{10} \\
(4)\end{array}$ & 3393 & 2937 & 1628 & 1363 & $\begin{array}{l}1495 \\
1455 \\
\end{array}$ & 459 & 599 & 768 \\
\hline $\begin{array}{c}\mathrm{C}_{22} \mathrm{H}_{32} \mathrm{~N}_{2} \mathrm{O}_{10} \mathrm{Zn} \\
\text { (5) }\end{array}$ & $\begin{array}{l}3505 \\
3402 \\
3341 \\
3302\end{array}$ & 2933 & 1608 & 1384 & $\begin{array}{l}1495 \\
1456\end{array}$ & 427 & 563 & 764 \\
\hline
\end{tabular}


In the spectral region $3300-3500 \mathrm{~cm}^{-1}$ a wide band formed by 2-3 overlapped bands is observed that may be assigned to $\mathrm{V}_{\mathrm{OH}}$ and $\mathrm{V}_{\mathrm{O}-\mathrm{H}-\mathrm{O}}$ vibration due intra- and intermolecular hydrogen bonding in the crystalline state. The vibrational frequencies related to $v\left(\mathrm{coo}^{-}\right)_{\text {as }}$ at $1651 \mathrm{~cm}^{-1}$ and $v\left(\mathrm{coo}^{-}\right)_{s}$ at $1411 \mathrm{~cm}^{-1}$ in ligand is shifted toward lower value in the spectra of the complexes with 25$48 \mathrm{~cm}^{-1}$ for the $v\left(\mathrm{coo}^{-}\right)_{\text {as }}$ and $23-51 \mathrm{~cm}^{-1}$ for the $v\left(\mathrm{coo}^{-}\right)_{s}$, respectively $[3,18]$. Modified are also observed in the case of $V_{N H}$ or $\delta_{N H}$ frequencies in the metal complexes comparative to the free ligand $[3,18]$. These bands of the metal complexes were shifted to lower value due to chelating with metal ions. The new bands appearing in the range $421-427 \mathrm{~cm}^{-1}$ are assigned to $v_{M-O}$, while those at 541-563 $\mathrm{cm}^{-1}$ could be attributed to $v_{M-N}$ [15-21]. In the case of all metal complexes a $v_{(M-H 2 O}$ vibration band appears at $763-768 \mathrm{~cm}^{-1}$, which is characteristic for coordinated water molecules in the inner coordination sphere [15].

\section{Thermal investigation}

The thermal decomposition of the ligand $L$ and its metal complexes (1-5) was studied by means of a derivatograph in air atmosphere. Thermal stability domains, decomposition phenomena and their assignments are summarized in Table 2 and Figure 3a-c.

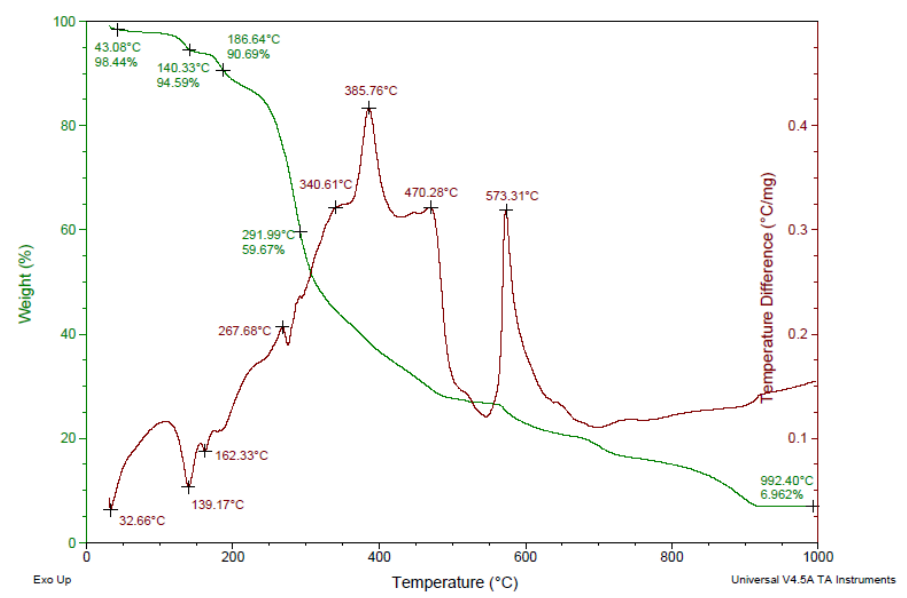

Figure 3a. TG-DTA diagram for the ligand $\mathbf{L}$

The thermal analysis results reveal that the ligand (L) is hydrated with a water molecule and the decomposition involved three steps. The first step of decomposition occurs within temperature range $20-187^{\circ} \mathrm{C}$ has three 
endothermic peaks at $33^{\circ} \mathrm{C}, 139^{\circ} \mathrm{C}$ and $162^{\circ} \mathrm{C}$. The first small endothermic peak with a mass loss of $1.56 \%$ represented the loss of residual water present in the pores, phenomenon which could be explained by the synthesis of the ligand from aqueous solution [13]. The next two peaks with a mass loss of $3.85 \%$ (calcd. $3.71 \%$ ), respectively $3.90 \%$ (calc. $3.70 \%$ ) could be assigned to loss very slowly the water molecule. Probably the water is held inside to ligand until the melting point (m.p. $=145-147^{\circ} \mathrm{C}$, lit. [13].) The second stage of decomposition was observed in the temperature range $187-292^{\circ} \mathrm{C}$ with an exothermic at $267^{\circ} \mathrm{C}$ and correspond to a glycine rest splitting (exp. $31.02 \%$, calcd. $32.86 \%)$.

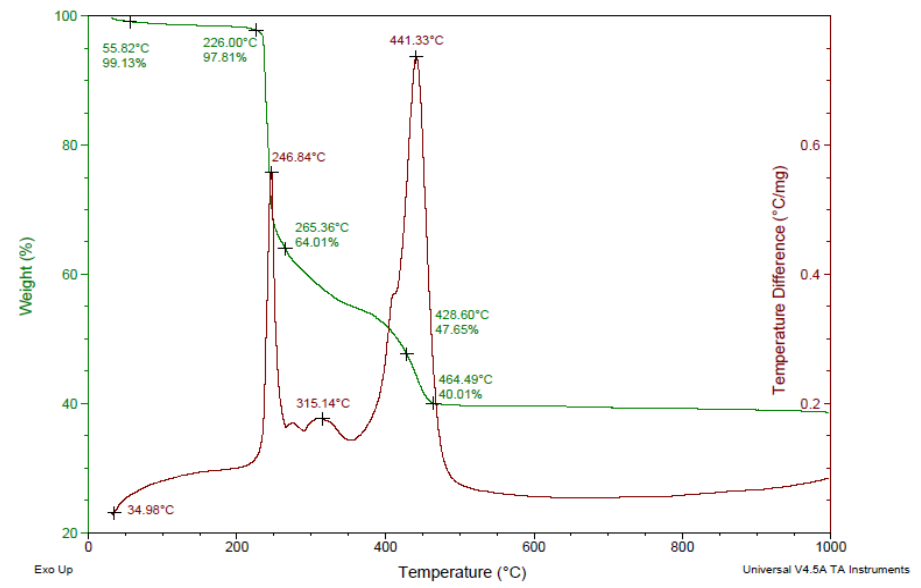

Figure 3b. TG-DTA diagram for the copper complex (1)

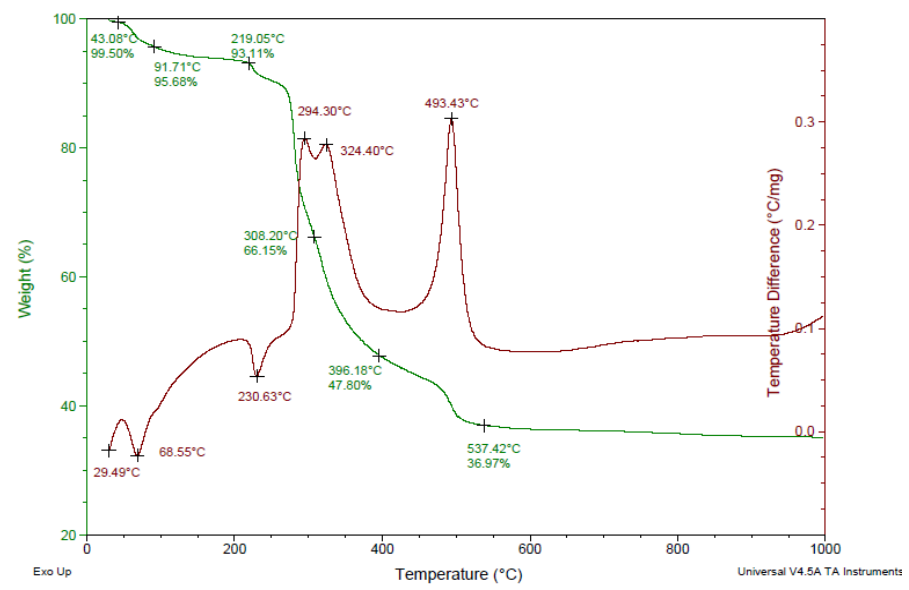

Figure 3c. TG-DTA diagram for the zinc complex (5) 
Table 2. Thermal analysis data of the ligand $L$ and its metal complexes (1-5) in air atmosphere $\left(10^{\circ} \mathrm{C} / \mathrm{min}\right)$

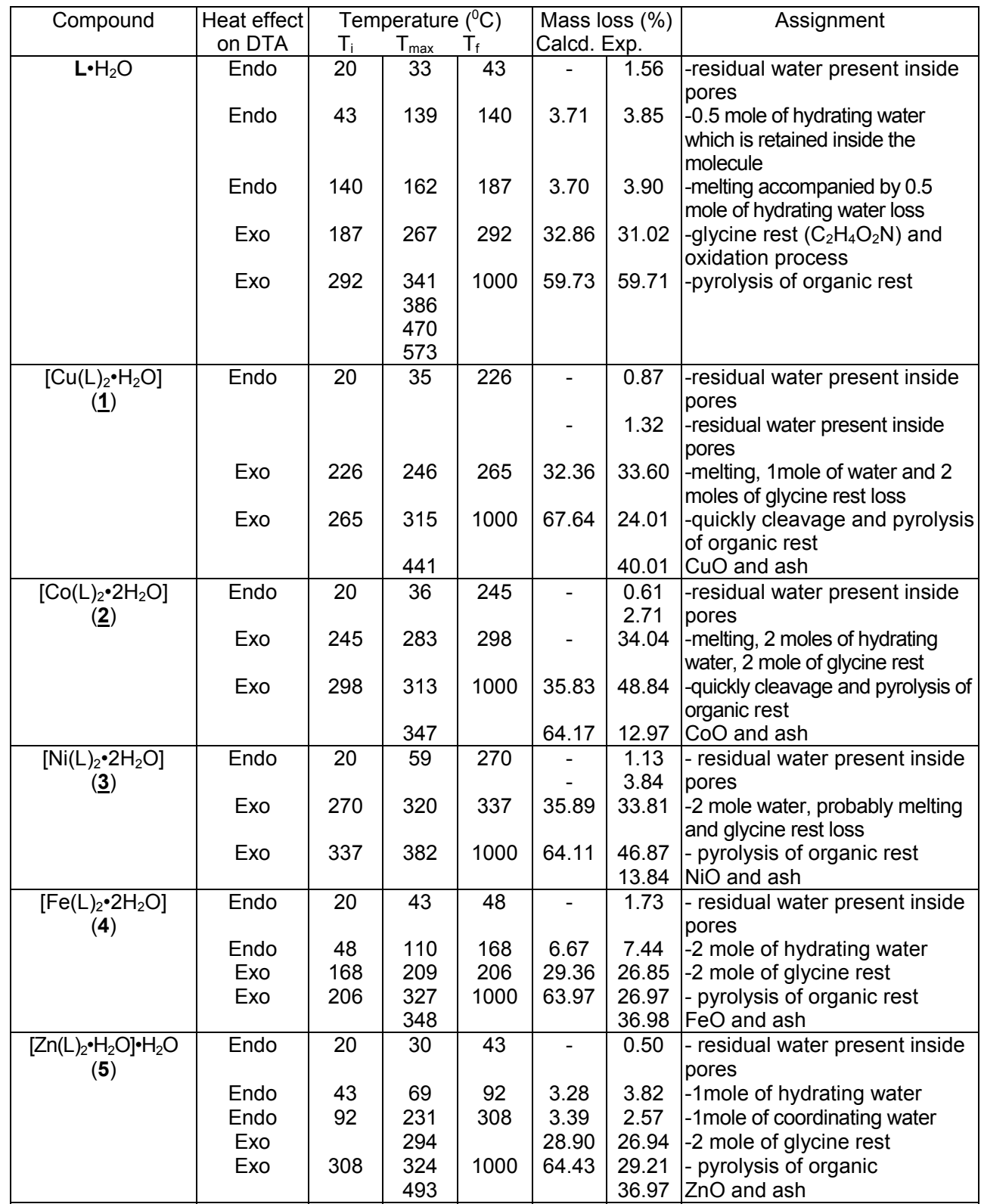

$\mathrm{T}_{\mathrm{i}}=$ initial temperature, $\mathrm{T}_{\max }=$ maximum temperature, $\mathrm{T}_{\mathrm{f}}=$ final temperature 
The aim of the thermal analysis of the metal complexes is to obtain information concerning their thermal stability of these and to decide whether the water molecules are inside or outside the coordination sphere.

The decomposition of each metal complex occurs in three steps.

The interval $20-270^{\circ} \mathrm{C}$ is characterized by endothermic peaks, which corresponds to the loss of residual waters present in the pores or the coordination water, except zinc complex. Between $207-337^{\circ} \mathrm{C}$, the exothermic peaks indicated the breaking of the glycine rest, then all the organic fragments decompose rapidly to the metal oxide. The metal complexes are completely pyrolyzed before $500^{\circ} \mathrm{C}$, except zinc complex, as follows: at $464^{\circ} \mathrm{C}$ for the $\mathrm{Cu}$-complex, at $357^{\circ} \mathrm{C}$ for the Co-complex, at $392^{\circ} \mathrm{C}$ for the Ni-complex, at $347^{\circ} \mathrm{C}$ for the Fe-complex and at $537^{\circ} \mathrm{C}$ for the $\mathrm{Zn}$-complex. Finally, the metal oxide and some ash remain in the crucible in all the cases.

For the zinc complex (5), the loss of one mole water at $69^{\circ} \mathrm{C}$ and the other at $231^{\circ} \mathrm{C}$ indicated that one is outside and the other inside the coordination sphere (Figure 3c).

On the other hand, the $\mathrm{Cu}(\mathrm{II}), \mathrm{Co}(\mathrm{II})$ and $\mathrm{Ni}(\mathrm{II})$ complex loss the water and the glycine rest simultaneous. The Fe(II) complex loss the coordination water separated from the glycine breaking.

\section{ESR spectra}

At room temperature the ESR spectrum of cooper (II) compound are typical for monomeric species with axial symmetry (Figure 4). The principal values of the $\mathbf{g}$ tensor $\left(\mathrm{g}_{\|}=2.427, \mathrm{~g}_{\perp}=2.063\right)$ correspond to a $\mathrm{CuN}_{2} \mathrm{O}_{3}$ local symmetry [23].

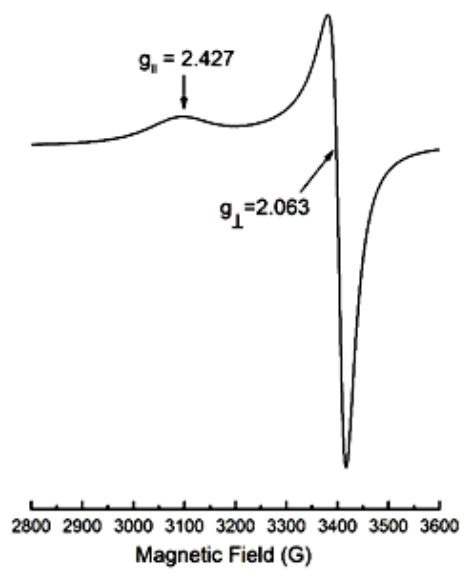

Figure 4. Powder ESR spectrum of copper complex at room temperature 


\section{CONCLUSIONS}

New transition metal complexes (1-5) of an $\mathrm{N}$-modified glycine (L) as ligand were synthesized and analyzed by elemental analysis, thermal stability in air atmosphere and spectral studies.

Mass spectra identify the $M+1$ peak corresponding for each of investigated compounds.

The study of UV-VIS spectra indicated a slight hypsochromic shift by 3.5-7.5 nm, but a considerable hyperchromic increase effect of absorbance comparative to the spectrum of the initial ligand (L), except $\mathrm{Zn}$ complex.

Elemental and thermal analysis lead to the idea that all the compounds, including the ligand are water hydrates. Except the ligand and the cooper complex all are hydrating with two water molecules. Based on the spectroscopic studies, the ligand has been found to coordinate the metal by the carboxylate oxygen and the nitrogen atom belonging to the amino group of the glycine fragment. On the other hand, an additional band appearing at 763-768 $\mathrm{cm}^{-1}$ confirms the coordinative $\mathrm{H}_{2} \mathrm{O}$-metal bonding, like the other similar complexes $[15,20]$.

The thermal stability of selected $3 d$ transition metal complexes was studied in air atmosphere in $20-1000^{\circ} \mathrm{C}$ temperature domain. Both the ligand and its metal complexes decompose in multistage.

On the basis of thermal and spectroscopic studies it was found that metal complexes stability: $\left[\mathrm{Fe}(\mathrm{L})_{2} \cdot 2 \mathrm{H}_{2} \mathrm{O}\right]<\left[\mathrm{Co}(\mathrm{L})_{2} \cdot 2 \mathrm{H}_{2} \mathrm{O}\right]<\left[\mathrm{Ni}(\mathrm{L})_{2} \cdot 2 \mathrm{H}_{2} \mathrm{O}\right]<$ $\left[\mathrm{Cu}(\mathrm{L})_{2} \cdot \mathrm{H}_{2} \mathrm{O}\right.$ ], except $\mathrm{Zn}$ complex, obeys the Irving-Williams series [17, 20, 22].

The obtained structural data allow us to propose the following molecular formulas for the studied metal complexes (Figure 5):
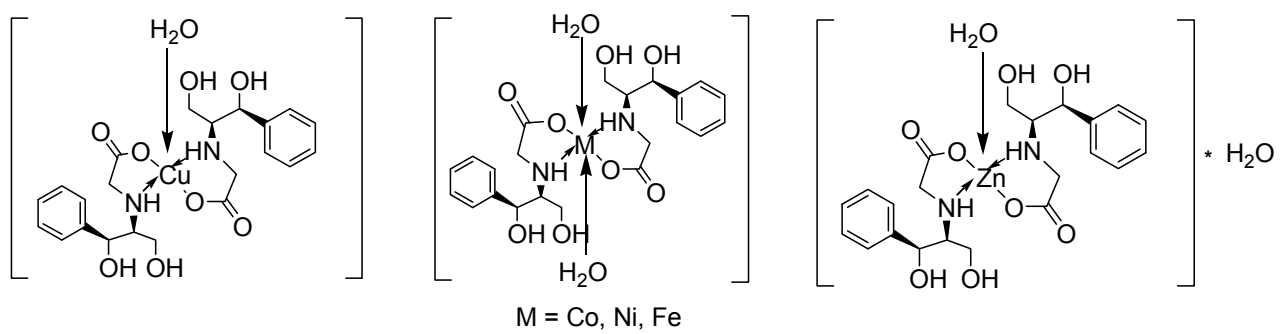

Figure 5. Suggested structure for the studied complexes 


\section{EXPERIMENTAL SECTION}

\section{Materials and instrumentation}

All reagents and chemicals were purchased from commercial sources and used as received. Elemental analyses were determined on Thermo Scientific Flash EA 1112 Elemental Analyzer. Melting points were measured on an ELECTROTHERMAL ${ }^{\circledR}$ instrument and and were not corrected. The electronic absorption spectra were performed on SHIMADZU UV-1800 spectrophotometer. Specific rotations were estimated on a Polamat A Karl Zeis Jena photopolarimeter. GC-MS spectra were recorded on a Gas Chromatograph with Mass Spectrometer Shimadzu ${ }^{\circledR}$ QP 2010 PLUS. Mass spectra were carried out on a LTQ ORBITRAP ${ }^{\circledR}$ XL (Thermo Scientific) instrument which was externally calibrated using the manufacturer's APCl for the ligand or $\mathrm{ESI}(+)$ calibration mix for metal complexes. The samples were introduced into the spectrometer by direct infusion. The ESR measurements were carried out on a Bruker Biospin EMXmicro spectrometer operating at X-band $(9-10 \mathrm{GHz})$ with continuous wave at $X$-band $(\approx 9 \mathrm{GHz})$. The spectra were recorded at room temperature with a microwave frequency of $9.4353 \mathrm{GHz}$, microwave power of $2 \mathrm{~mW}$, modulation frequency of $100 \mathrm{kHz}$, modulation amplitude of $2 \mathrm{G}$. IR spectra were recorded in $\mathrm{KBr}$ pellets on a JASCO $®$ FT-IR 6200 Spectrometer which operates with $4 \mathrm{~cm}-1$ resolution Thermogravimetry and differential thermal analysis (TG/DTA) curves were recorded with a Thermal Analyzer TA Instruments SDT Q600 V20.9 Build 20 on an interval 20-10000C, at a heating rate of $10^{\circ} \mathrm{C} / \mathrm{min}$, in alumina crucibles and a dynamic air atmosphere.

\section{General synthesis of the metal complexes}

The ligand $\mathbf{L}$ was prepared by a literature procedure we have been working on, by treatment of [(1S,2S)-2-amino-1-phenylpropane-1,3-diol] namely phenylserinol with monochloroacetic acid/ $\mathrm{Na}_{2} \mathrm{CO}_{3}$ system, TLC monitored $\left[R_{f}=0.65\right.$. (methanole: water $\left.\left.=1: 1 \mathrm{v} / \mathrm{v}\right)\right]$, then investigated by spectroscopic methods [13].

$\mathrm{Cu}(\mathrm{II}), \mathrm{Co}(\mathrm{II}), \mathrm{Ni}(\mathrm{II}) \mathrm{Fe}(\mathrm{II})$ and $\mathrm{Zn}(\mathrm{II})$ complexes of the ligand $\mathrm{L}$ were prepared by following a general method. The metal salt $\left[\mathrm{Cu}\left(\mathrm{NO}_{3}\right)_{2} \cdot 3 \mathrm{H}_{2} \mathrm{O}\right.$, $\mathrm{Co}\left(\mathrm{NO}_{3}\right)_{2} \cdot 6 \mathrm{H}_{2} \mathrm{O} \mathrm{Ni}\left(\mathrm{NO}_{3}\right)_{2} \cdot 6 \mathrm{H}_{2} \mathrm{O}, \mathrm{FeSO}_{4} \cdot 7 \mathrm{H}_{2} \mathrm{O}$, or $\mathrm{ZnSO}_{4} \cdot 7 \mathrm{H}_{2} \mathrm{O}(1.24 \mathrm{mmol})$ was dissolved in $10 \mathrm{~mL}$ distilled water. To a solution of ligand (L) $(2 \mathrm{mmol})$ dissolved in $3 \mathrm{~mL}$ of distilled water, was added slowly, dropwise during $30 \mathrm{~min}$, a solution of the metal salt, at room temperature. The mixture was let to stir at the room temperature for $24 \mathrm{~h}$. By adding a solution of metal ions to a solution of ligand, immediate color change was observed depending on the 
metal ion. The isolated solid complexes were obtained by vacuum filtration and washed with distilled water and finally dried in air at room temperature for $48 \mathrm{~h}$. The dried complexes were subjected to elemental, spectroscopic and thermal analysis.

$\mathrm{C}_{22} \mathrm{H}_{30} \mathrm{CuN}_{2} \mathrm{O}_{9}$ (1) Pale-blue solid, $\mathrm{MW}=530.0276, \mathrm{Mp}=247-248^{\circ} \mathrm{C}$ (desc.) Yield: $64.16 \%$, Elemental Analysis (\%) Calc.(Found) C: 49.85(48.32), $\mathrm{H}: 5.71(5.31), \mathrm{N}: 5.29(6.11)$, UV-ViS (DMSO): $\lambda_{\max }=268.5 \mathrm{~nm}, \mathrm{~A}=0.333 \varepsilon=$ 11743.96, IR(KBr): $v_{\text {max.: }}$ 3293, 3034, 1613, 1386, 1494, 1456, 763, 541, 421, MS (ESI, $\mathrm{CH}_{3} \mathrm{OH}$, without hydrating water) [M+1]: 512.1216 Exact Mass: 511.1142, $[\alpha]_{546^{25}}=+36$ (c=0.1, DMSO), Thermal Analysis: $35^{\circ} \mathrm{C}$ (Endo) ( $T G_{\text {exp. }}$. $=2.19 \%), 246^{\circ} \mathrm{C}($ Exo $)\left(\mathrm{TG}_{\text {calc. }}=32.36 \%, \mathrm{TG}_{\text {exp. }}=33.60 \%\right),($ Exo $) 315^{\circ} \mathrm{C}, 441^{\circ} \mathrm{C}$ $\left(\mathrm{TG}_{\text {calc. }}=67.64 \%, \mathrm{TG}_{\text {exp. }}=64.01 \%\right)$, Molar Ratio M: $\mathrm{L}: \mathrm{H}_{2} \mathrm{O}=1: 2: 1$.

$\mathrm{C}_{22} \mathrm{H}_{32} \mathrm{CoN}_{2} \mathrm{O}_{10}$ (2) White-pink solid, $\mathrm{MW}=543.4301, \mathrm{Mp}=289-290^{\circ} \mathrm{C}$ (desc.), Yield: 57.26\%, Elemental Analysis (\%) Calc.(Found) C: 48.62(46.93), $\mathrm{H}: 5.94(5.82)$, N: 5.15(6.03), UV-ViS (DMSO): $\lambda_{\max }=269.5 \mathrm{~nm}, \mathrm{~A}=0.299 \varepsilon=$ 10826.66, IR(KBr): $v_{\text {max.: }} 3324,3086,1600,1383,1493,1456,763,561,429$, MS (ESI, $\mathrm{CH}_{3} \mathrm{OH}$, without hydrating water) $[\mathrm{M}+1]$ : 508.1255 Exact Mass: 507.1178, $[\alpha]_{546^{25}}=+11$ (c=0.1, DMSO), Thermal Analysis: $36^{\circ} \mathrm{C}$ (Endo) ( $\mathrm{TG}_{\text {exp. }}$. $=3.32 \%), 283^{\circ} \mathrm{C}(\mathrm{Exo})\left(\mathrm{TG}_{\text {calc. }}=35.83 \%, \mathrm{TG}_{\text {exp. }}=34.04 \%\right),(\mathrm{Exo}) 313^{\circ} \mathrm{C}$, $347^{\circ} \mathrm{C}\left(\mathrm{TG}_{\text {calc. }}=64.17 \%, \mathrm{TG}_{\text {exp. }}=61.81 \%\right)$, Molar Ratio M: $\mathrm{L}: \mathrm{H}_{2} \mathrm{O}=1: 2: 2$.

$\mathrm{C}_{22} \mathrm{H}_{32} \mathrm{~N}_{2} \mathrm{NiO}_{10}$ (3) White-greenish solid, $\mathrm{MW}=543.1903, \mathrm{Mp}=320-$ $321^{\circ} \mathrm{C}$ (desc.), Yield: 62.87\%, Elemental Analysis (\%) Calc.(Found) C: 48.65(49.17), H: 5.94(5.31), N: 5.16(6.23), UV-ViS (DMSO): $\lambda_{\max }=269.5 \mathrm{~nm}$, $A=0.171 \varepsilon=9270.805, \mathrm{IR}(\mathrm{KBr}): \mathrm{v}_{\text {max. }}: 3316,3086,1603,1385,1494,1456$, $763,564,432, \mathrm{MS}\left(\mathrm{ESI}, \mathrm{CH}_{3} \mathrm{OH}\right.$, without hydrating water) [M+1]: 507.1277 Exact Mass: $506.1197,[\alpha]_{546}{ }^{25}=+29$ (c=0.1, DMSO), Thermal Analysis: $59^{\circ} \mathrm{C}$ (Endo) $\left(\mathrm{TG}_{\text {exp. }}=4.97 \%\right), 320^{\circ} \mathrm{C}(\mathrm{Exo})\left(\mathrm{TG}_{\text {calc. }}=35.89 \%, \mathrm{TG}_{\text {exp. }}=33.81 \%\right)$, (Exo) $382^{\circ} \mathrm{C},\left(\mathrm{TG}_{\text {calc. }}=64.11 \%, \mathrm{TG}_{\text {exp. }}=60.71 \%\right)$, Molar Ratio M: L: $\mathrm{H}_{2} \mathrm{O}=1: 2: 2$.

$\mathrm{C}_{22} \mathrm{H}_{32} \mathrm{FeN}_{2} \mathrm{O}_{10}$ (4) Brown solid, $\mathrm{MW}=540.1406, \mathrm{Mp}=224-225^{\circ} \mathrm{C}$ (desc.), Yield: 63.12\%, Elemental Analysis (\%) Calc.(Found) C: 48.90(48.25), $\mathrm{H}: 5.97(5.34), \mathrm{N}: 5.18(6.02)$, UV-ViS (DMSO): $\lambda_{\max }=265.5 \mathrm{~nm}, \mathrm{~A}=0.394 \varepsilon=$ 14187,97, IR(KBr): $v_{\max }: 3393,2937,1628,1363,1495,1455,768,599,459, \mathrm{MS}$ (ESI, $\mathrm{CH}_{3} \mathrm{OH}$, without hydrating water) [M+1]: 505.1233 Exact Mass: 504.1195, $[\alpha]_{546}{ }^{25}=+21$ (c=0.1, DMSO), Thermal Analysis: $43^{\circ} \mathrm{C}$ (Endo) $\left(\mathrm{TG}_{\text {exp. }}=1.73 \%\right.$ ), $110^{\circ} \mathrm{C}$ (Endo) $\left(\mathrm{TG}_{\text {calc. }}=6.67 \%, \mathrm{TG}_{\text {exp. }}=7.44 \%\right),($ Exo $) 209{ }^{\circ} \mathrm{C},\left(\mathrm{TG}_{\text {calc. }}=29.36 \%\right.$, $\left.\mathrm{TG}_{\text {exp. }}=26.85 \%\right)$, (Exo) $327^{\circ} \mathrm{C}, 348^{\circ} \mathrm{C}\left(\mathrm{TG}_{\text {calc. }}=63.97 \%, \mathrm{TG}_{\text {exp. }}=63.95 \%\right)$ Molar Ratio M: L: $\mathrm{H}_{2} \mathrm{O}=1: 2: 2$. 
$\mathrm{C}_{22} \mathrm{H}_{32} \mathrm{~N}_{2} \mathrm{O}_{10} \mathrm{Zn}$ (5) White solid, $\mathrm{MW}=549.8869, \mathrm{Mp}=290-291^{\circ} \mathrm{C}$ (desc.), Yield: 55.26\%, Elemental Analysis (\%) Calc.(Found) C: 48.02(47.45), $\mathrm{H}: 5.87(4.98), \mathrm{N}: 5.09(5.82)$, UV-ViS (DMSO): $\lambda_{\max }=268 \mathrm{~nm}, \mathrm{~A}=0.084 \varepsilon=$ 4604.5, IR(KBr): $v_{\text {max. }}: 3505,3402,3341,3302,2933,1608,1384,1495,1456$, 764, 563, 427, MS (ESI, $\mathrm{CH}_{3} \mathrm{OH}$, without hydrating water) [M+1]: 513.5406 Exact Mass: $512.1137,[\alpha]_{546}{ }^{25}=+18$ (c=0.1, DMSO), Thermal Analysis: $30^{\circ} \mathrm{C}$ (Endo) $\left(\mathrm{TG}_{\text {exp. }}=0.50 \%\right), 69^{\circ} \mathrm{C}$ (Endo) $\left(\mathrm{TG}_{\text {calc. }}=3.28 \%, \mathrm{TG}_{\text {exp. }}=3.82 \%\right)$, (Endo) $231^{\circ} \mathrm{C},\left(\mathrm{TG}_{\text {calc. }}=3.39 \%, \mathrm{TG}_{\text {exp. }}=2.57 \%\right),($ Exo $) 294^{\circ} \mathrm{C},\left(\mathrm{TG}_{\text {calc. }}=28.90 \%, \mathrm{TG}_{\text {exp. }}=\right.$ $26.94 \%)($ Exo $) 324^{\circ} \mathrm{C}, 493^{\circ} \mathrm{C}\left(\mathrm{TG}_{\text {calc. }}=64.43 \%, \mathrm{TG}_{\text {exp. }}=66.18 \%\right)$ Molar Ratio $\mathrm{M}: \mathrm{L}: \mathrm{H}_{2} \mathrm{O}=1: 2: 2$.

\section{ACKNOWLEDGMENTS}

Authors acknowledge the financial support from a Grant provided by the Research Council Romania (project PN-II-ID-PCE-2011-3-0128).

Special thanks are addressed to Conf. Dr. Petru Pascuta from Technical University of Cluj-Napoca, Faculty of Material and Environmental Engineering, for the IR spectra measurements and to Dr. Mirabela-Ligia Golban from the Faculty of Chemistry and Chemical Engineering for the HRMS and UV-VIS spectra.

\section{REFERENCES}

1. I. Sakiyan, E. Loğoğlu, S. Arslan, N. Sari, N. Sakiyan, BioMetals, 2004, 17(2), 115.

2. A. Temitayo, O. Isaac, A. Olugbenga, International Journal of Chemistry, 2012, 4(2), 49.

3. A. Marcu, A. Stanila, D. Rusu, M. Rusu, O. Cozar, L. David, Journal of Optoelectronics and Advanced Materials, 2007, 9(3), 741.

4. G. Indira Devi, P. Smitha, International Research Journal of Biological Sciences, 2013, 2(6), 16.

5. N. Barooah, R. J. Sarma, A. S. Batsanov, J. B. Baruh, Polyhedron, 2006, 25(1), 17.

6. S. Begum, S. S. Nizami, S. Saied, S. M. Shahid, F. Z. Basha, European Journal of Chemistry, 2014, 5(4), 557.

7. L. Menabue, M. Saladini, Journal of Crystallographic and Spectroscopic Research, 1992, 22(6), 713.

8. K. Nishimura, X. Lu, R. B. Silverman, Journal of Medicinal Chemistry, 1993, 36, 446.

9. G. Byk, C. Gilon, Journal of Organic Chemistry, 1992, 57, 5687.

10. C. M. Sharaby, M. F. Amine, A. A. Hamed, Journal of Molecular Structure, 2017, 1134, 208. 
11. F. Sevgi, U. Bagkesici, A. N. Kursumlu, E. Guler, Journal of Molecular Structure, 2018, 1154, 256.

12. C. Sacalis, F. Goga, L. David, Studia UBB Chemia, 2017, 62(4), Tom I, 181.

13. O. Moldovan, K. Albert, I. Nagy, C. Morar, C. Sacalis, M. Darabantu, Tetrahedron Letters, 2016, 57, 5808.

14. L. Zapala, M. Kosińska, E. Woźnicka, L. Byczyński, W. Zapala, Journal of Thermal Analysis and Calorimetry, 2016, 124, 363.

15. C. Batiu, L. Ghizdavu, L. David, O. Cozar, Synthesis and Reactivity in Inorganic and Metal-Organic Chemistry, 2003, 33(8), 1391.

16. A. A. El-Asmy, M. A. Hafez, E. M. Saad, F. I. Taha, Transition Metal Chemistry, 1994, 19, 603.

17. L. David, C. Craciun, C. Balan, O. Cozar, L. Ghizdavu, C. Batiu, Acta Chimica Slovenica, 2001, 48, 407.

18. F. H. A. Al-Jeboori, T. A. M. Al-Shimiesawi, Journal of Chemical and Pharmaceutical Research, 2013, 5(11), 318.

19. R. A. Ammar, S. I. Al-Saeedi, A-N. M. A. Alaghaz, International Journal of Electrochemical Science, 2018, 13, 3700.

20. C. Batiu, C. Jelic, N. Leopold, O. Cozar, L. David, Journal of Molecular Structure, 2005, 744-747, 325.

21. M. Castillo, E. Ramirez, Transition Metal Chemistry, 1984, 9(7), 268.

22. H. M. N. H. Irving, R. J. P. Williams, Journal of the Chemical Society, 1953, 3192.

23. A. Bencini, D.Gatteschi, "Transition Metal Chemistry", Marcel Dekker, New York, NY, 1982, 8. 
